\title{
The state of the Russian payment market: digitalization and the impact of COVID-19
}

\author{
Olga Korobeynikova ${ }^{1 *}$, Diana Burkaltseva ${ }^{2}$, Tatiana Dugina $^{3}$, Zinaida Kozenko ${ }^{3}$, and \\ Svetlana Shaldokhina ${ }^{3}$ \\ ${ }^{1}$ Volgograd State Technical University, 400005, Lenina Avenue, 28, Volgograd, Russia \\ ${ }^{2}$ V.I. Vernadsky Crimean Federal University, 295007, Vernadskogo Avenue, 4, Simferopol, Republic \\ of Crimea, Russia \\ ${ }^{3}$ Volgograd State Agrarian University, 400002, University Avenue, 26, Volgograd, Russia
}

\begin{abstract}
The purpose of the article is to assess the state of the Russian payment market and the impact on it of two main factors the COVID-19 pandemic and the development of the digital economy. Objectives of the article: 1) highlight the stages of development of the modern payment market in Russia; 2) identify the dynamics of the payment market of the Russian Federation (infrastructure for the provision of payment and other financial services, the number of non-cash payments, the use of cash); 3) to establish the impact of the COVID-19 pandemic and the development of the digital economy on the state of the Russian payment market. As a result of solving the tasks, the following was established. There are three stages to assess the Russian payment market. Analysis of data on the infrastructure for the provision of payment and other financial services showed that since 2010 there has been an annual decrease in the number of banks. The structure of non-cash payments is changing: the number and amount of transactions using payment cards are growing, the number and volume of money transfers are decreasing, and cash is being phased out. The impact of the COVID-19 pandemic and digitalization on the state of the Russian payment market reflects trends that are being strengthened by the pandemic and are shaping a sustainable trend.
\end{abstract}

\section{Introduction}

The transformation of the payment services market in Russia is taking place against a rapidly changing and poorly predictable background of epidemic, technological and other challenges. We highlight two main factors that today determine the state of the Russian payment market: COVID-19 and the digital economy. COVID-19 and the digital economy

*Corresponding author: korobeinikov77@yandex.ru 
are making significant changes not only in the ecosystem landscape, the structure of payment services, product offerings, but also in the dynamics of the ongoing transformations. These factors are interrelated, but they are multidirectional. It is obvious that the pandemic has a destructive, destructive effect on the economy, finance, payments market, consumers and producers, etc. [2]. The digital economy is a growth factor that has a constructive and constructive effect on the market, communications, economic growth, etc. [29].

The payments sector is distinguished by its ability to intensively diffuse innovations into its own internal environment. This contributes to the transformation of product offerings, technologies for external communications and internal generalization, processing, transfer and storage of data, organizational structure, etc. As a result, payment market actors - payment systems, payment service providers, banks, and other intermediaries - can communicate and accelerate digital innovation to external actors. Consumers of payment services (subjects of the external environment) acquire a special, innovation-oriented, digital culture through digital interaction with subjects of the payment market. That is, there is a mutual "infection" of the payment market participants with digital innovations. The COVID-19 pandemic in Russia has become a driver of digitalization in the financial, payment and other intermediary sectors [12].

The COVID-19 pandemic in Russia and in the world has caused not only economic problems, but also an explosive growth in the number and volume of remote payment transactions. Banks and other payment intermediaries began to adjust to the new reality. To maintain a customer base, Russian banks are developing digital technologies, creating digital ecosystems, digital services and products. A similar situation is developing in other countries. For example, in China in 2003, the SARS epidemic became the main catalyst for the development of digital payments and e-commerce. During that period, China created the innovative mobile payment system WeChat Pay, despite the fact that most citizens did not even have access to a bank account. Therefore, Joseph Stiglitz rightly calls the coronavirus a tax on human activities associated with close human contact [26]. The disproportionality of such a "tax" made any offline services unprofitable or impossible and forced to invest in digitalization ("... the pandemic will continue to stimulate significant changes in the structure of consumption and production, which, in turn, will lead to broader structural changes ..." [26]).

These data indicate that the payment market and the financial sector as a whole were least affected by the impact of negative factors. Moreover, they got a chance to grow thanks to their internal ability to transform, generate innovative technologies and accelerate their promotion in the client environment.

The purpose of the article is to assess the state of the Russian payment market and the impact on it of two main factors - the COVID-19 pandemic and the development of the digital economy. Objectives of the article: 1) highlight the stages of development of the modern payment market in Russia; 2) identify the dynamics of the payment market of the Russian Federation (infrastructure for the provision of payment and other financial services, the number of non-cash payments, the use of cash); 3) to establish the impact of the COVID-19 pandemic and the development of the digital economy on the state of the Russian payment market.

\section{Materials and Methods (Model)}

In the course of the study, the authors used methods of generalization and comparison of data, formalization of the characteristics of the research object, as well as empirical methods of observation and description of the research area. The study of the state of the Russian payment market is based on the principles of a historical approach, objectivity, complexity, and consistency. 
The principle of the historical approach is applied to the study of the payment market, not only taking into account the traditional factors of the socio-economic development of Russia, but also taking into account new pandemic threats and new digital technologies. The principle of objectivity consists in using a wide range of information sources, statistical and analytical materials from the Bank of Russia, and the results of expert research. The principle of the complexity of the study manifested itself in a comprehensive and interconnected study of the state of the Russian payment services market. The use of the principle of consistency made it possible to identify trends and patterns in changes in the payment services market under the influence of new pandemic threats and new digital technologies.

Analysis of the theoretical and methodological base of this research area showed that the issues of theory and methodology of money circulation, financial markets, financial and payment services were considered in the works of Baydukova N, Vasilyev S, Chepakov D [4], Elmquist M, Gawer A, Le Masson P [ 8], Ercevik K, Jackson J [9], Korobov Yu I [14], Semenyuta O, Panchenko N [23], Stiglitz JE [27], Stiglitz J, Bhattacharya A [28] etc. Digital innovations and innovative technologies in entrepreneurship and payments, Akimova OE, Volkov SK, Kabanov VA, Ketko NV, Kuzlaeva I [1], Babkin AV, Burkaltseva DD, Pshenichnicov VV, Tyulin AC [3], Bech ML, Hobijn B [5], Bech M , Preisig C, Soramaki K [6], Gawer A, Cusumano M [10], Leinonen H, Soramaki [16], Levine R, Loayza N, Beck T [17], Piotr Masiukiewicz, Paweł Dec [18], S. Muegge [19], Nelson R, Phelps E [20], Skokov RYu [24], Volkov SK, Gushchina EG, Vitaleva EM [31], etc.

\section{Results and Discussion}

In the development of the modern payment market in Russia, we distinguish the following stages:

Stage I - adoption of the federal law "On the national payment system" (2011-2013). The law became an incentive for the growth of the number of participants in the payment market, the number of transactions;

Stage II - the application of external sanctions to the Russian economy, restriction of access to international financing markets (2014-2016);

Stage III - the development of the digital economy in Russia (2016 -...);

Stage IIIA (IV?) - the emergence of pandemic shocks and the manifestation of pandemic restrictions $(2020-\ldots)$.

The identification of stages in this time frame is necessary for an adequate assessment of the state of the Russian payment market and is associated with several reasons. First, the unidirectional dynamics of indicators in different periods is caused by different factors. Secondly, the influence of one and the same factor in different periods manifests itself with different strengths [15]. Thirdly, the factors influencing the development of the payment market in different periods are divided into manageable and uncontrollable, predictable and unpredictable.

The state of the payment market in the Russian Federation is characterized by data from the Bank of Russia:

- on the infrastructure for the provision of payment and other financial services;

- about the number of non-cash payments;

- about the use of cash.

Data on changes in the number of banks and other institutions of the banking system in total and per 1 million people are shown in Figures 1 and 2. 


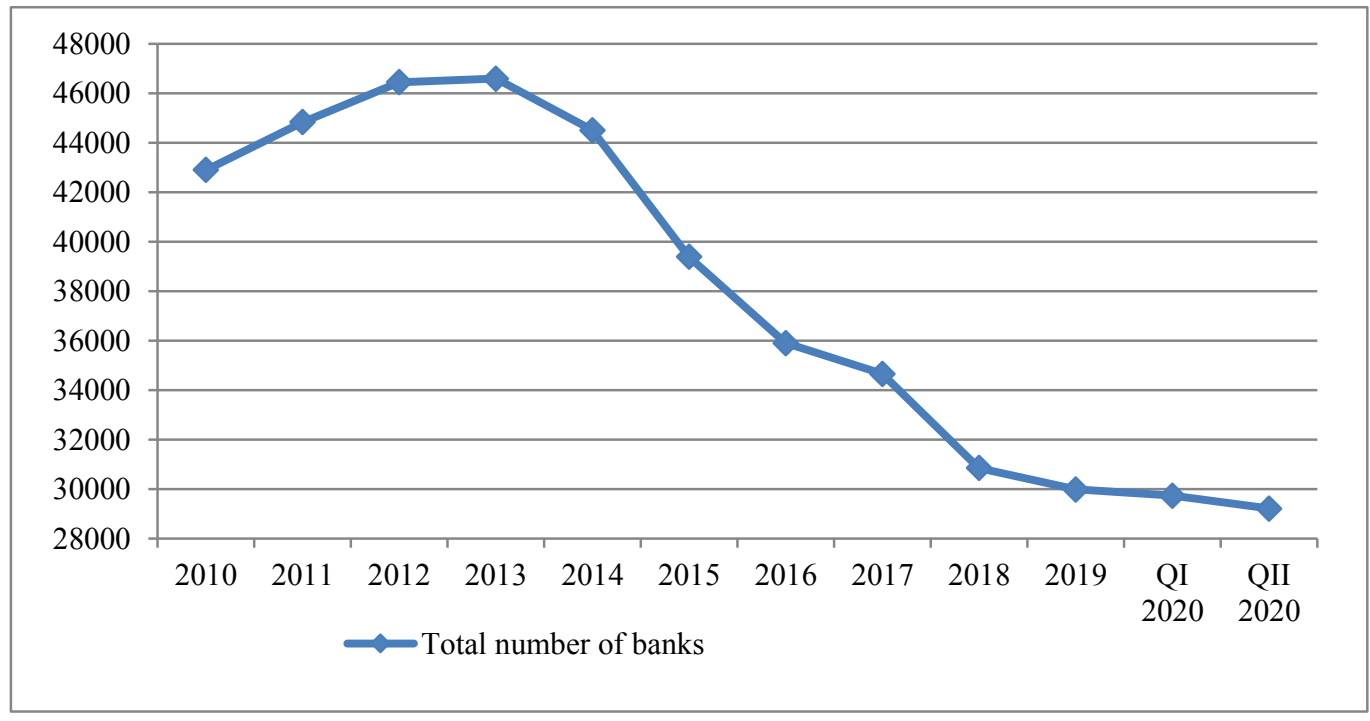

Fig. 1. Dynamics of institutional provision of payment services in Russia, units

The starting point (beginning of stage I) is 2010. In Russia adopted a federal law about "The national payment system" (2010). This law establishes the general procedure for the functioning of the national payment system and its participants, which include banking organizations. Therefore, we see an increase in the number of banking institutions until 2013, which is explained by the operation of the law and new opportunities that have been created in the payment market. But after 2013, there has been a decrease in the number of banking organizations. The beginning of the recession is associated with external shocks, the impact of economic sanctions on the Russian economy, and restrictions on the access of Russian banks to international financing markets. Due to macroeconomic difficulties, the Bank of Russia pursued a tough policy of liquidating weak banks and reorganizing the banking system. The fall also continued in the first half of 2020. It was not caused by the revocation of banking licenses by the Bank of Russia, but the liquidation of banks due to the COVID-19 pandemic. The pandemic caused a general decrease in consumer demand around the world and in Russia, and a decrease in payment turnover, attraction of deposits, and issuance of loans. For 2010 - Q3 2020, there is a general decrease in banking system institutions by 13689 units or $31.91 \%$.

Figure 2 shows that Russia is not only optimizing the total number of subjects of the banking system by reducing the number of banks. There is also a decrease in the number of banks per 1 million inhabitants. For 2010 - Q3 2020, there is a decrease in the provision of Russian citizens with banking organizations. During the study period, the number decreased by 100 banks per 1 million of the population, or by $33.11 \%$. This dynamics shows a quantitative deterioration in the availability of financial (including payment) services for the Russian population. But at the same time, the high-quality availability of financial services has improved - digital services, digital banking ecosystems, and integrated digital products have appeared. 


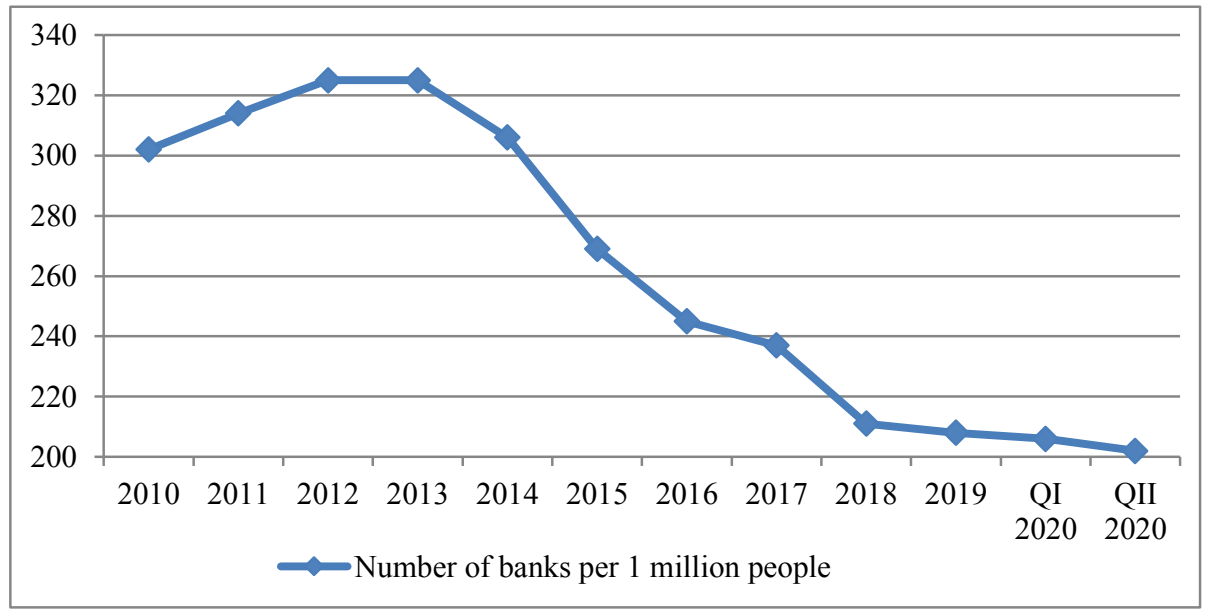

Fig. 2. Provision of the Russian population with payment services per 1 million people, units

The improvement in quality accessibility is indicated by data on the volume of transactions in the retail segment of the payment market. The total volumes and number of transactions in the retail segment have similar dynamics with the institutional provision of the retail market with payment services. The data confirm the thesis about the replacement of traditional services of banking intermediaries with innovative digital services (Table 1).

Table 1. Indicators of retail payment transactions in the payment market of the Russian Federation.

\begin{tabular}{|c|c|c|c|c|c|c|}
\hline Period & $\begin{array}{c}\text { Money transfers without } \\
\text { opening a bank account of } \\
\text { a payer-individual }\end{array}$ & $\begin{array}{c}\text { Cash withdrawal using } \\
\text { payment cards of Russian } \\
\text { banks }\end{array}$ & $\begin{array}{c}\text { Cashless transactions with } \\
\text { payment cards of Russian } \\
\text { banks }\end{array}$ \\
\cline { 2 - 7 } & $\begin{array}{c}\text { number, } \\
\text { million } \\
\text { units }\end{array}$ & $\begin{array}{c}\text { volume, RUB } \\
\text { bln }\end{array}$ & $\begin{array}{c}\text { number, } \\
\text { million } \\
\text { units }\end{array}$ & $\begin{array}{c}\text { volume, RUB } \\
\text { bln }\end{array}$ & $\begin{array}{c}\text { number, } \\
\text { million } \\
\text { units }\end{array}$ & $\begin{array}{c}\text { volume, RUB } \\
\text { bln }\end{array}$ \\
\hline 2010 & 1336.5 & 3174.6 & 2068.3 & 10958.8 & 1039.0 & 1674.7 \\
\hline 2011 & 1279.5 & 3674.0 & 2448.6 & 14029.8 & 1677.5 & 3177.6 \\
\hline 2012 & 1235.9 & 4093.0 & 2845.8 & 18033.8 & 2930.7 & 5048.2 \\
\hline 2013 & 1301.1 & 4268.1 & 3132.5 & 21241.0 & 4355.1 & 7380.8 \\
\hline 2014 & 1257.9 & 4352.8 & 3275.4 & 23826.1 & 6487.6 & 11173.4 \\
\hline 2015 & 1141.8 & 4100.0 & 3298.7 & 24917.2 & 9525.2 & 15596.9 \\
\hline 2016 & 1034.8 & 3613.4 & 3443.5 & 27167.3 & 14040.9 & 22961.5 \\
\hline 2017 & 900.7 & 3371.8 & 3309.9 & 27044.6 & 20141.7 & 34940.3 \\
\hline 2018 & 773.6 & 3043.6 & 3176.4 & 27859.2 & 28556.8 & 48387.8 \\
\hline $2019:$ & 652.7 & 2576.6 & 3067.0 & 28574.5 & 38610.7 & 62357.8 \\
Q I & 160.6 & 613.9 & 707.8 & 6168.1 & 8067.1 & 12777.9 \\
Q II & 158.9 & 611.7 & 797.5 & 7119.7 & 9478.9 & 14857.1 \\
Q III & 160.7 & 704.9 & 776.9 & 7466.3 & 10099.7 & 16250.5 \\
Q IV & 172.4 & 646.2 & 784.8 & 7820.5 & 10965.0 & 18472.3 \\
\hline $2020:$ & & & & & & \\
Q I & 134.3 & 525.8 & 680.6 & 6737.3 & 10869.9 & 16834.7 \\
\hline
\end{tabular}




\begin{tabular}{|l|l|l|l|l|l|l|}
\hline Q II & 106.2 & 362.4 & 555.4 & 6177.1 & 10385.5 & 16545.2 \\
\hline
\end{tabular}

We consider the data on the number of non-cash payments of the population in two aspects. Firstly, these are money transfers without opening a bank account. Secondly, these are non-cash transactions made using payment cards.

Orders to transfer funds without opening a bank account are classified as traditional credit transfers. Transfers are made by payers - individuals with personal (as a rule) contacting bank offices. Since 2010, there has been a consistent decrease in both the number of transfers (more than two times in 2019 in relation to 2010) and their total volume (by $18.84 \%$ in 2019 in relation to 2010). The most noticeable decline has been taking place since 2014. This is mainly due to external factors and a decrease in crossborder transfers to neighboring countries [17]. Also, the acceleration of the rate of decline was significantly influenced by the development of card transactions [13]. That is, there was a restructuring of payments from the population: the reduction in remittances was offset by the growth of card transactions. The development of the digital economy at stage III accelerated the decline in the number and amounts of money transfers without opening an account. Pandemic shocks have also had a negative impact on payment activity in remittances. If in the II quarter of 2019 there were 158.9 million units. transfers in the amount of 611.7 billion rubles, then in the II quarter of 2020 - only 106.2 million units. in the amount of 362.4 billion rubles. (decrease by $33.17 \%$ and $40.76 \%$, respectively).

The indicators of non-cash payments of the population are mainly characterized by transactions with payment cards. The payment market in Russia uses contact and contactless cards, virtual cards, and other types of cards [25]. Payment cards are the most popular payment instrument. In contrast to the indicators of non-cash transfers and settlements in cash, we observe annual growth in the use of payment cards: since 2010, there has been a 37 -fold increase in the number and volume of card transactions. But even despite the overall growth in the second quarter of 2020 , there is a decrease in the number of transactions by $5.28 \%$ compared to the second quarter of 2019 and a decrease in the volume of transactions by $10.43 \%$ compared to the second quarter of 2019. for COVID- 19 . The outstripping decline in the volume of transactions in comparison with the number of transactions is explained by the reduction in household income and the forced saving of household resources.

We will consider the data on the use of cash in payment turnover using the example of cash withdrawal operations using payment cards of Russian credit organizations. Since 2015, significant changes have taken place in the Russian market of card payment systems. In 2010-2014. the main share of payment cards was issued by global payment systems Visa and Mastercard [7]. In 2015, the Russian National Payment Card System was created, which issues MIR cards. Despite the fact that MIR cards are a payment instrument only within the Russian Federation, the share of these cards has grown significantly, cards of global payment systems have been partially squeezed out of the market. The growth in the number of "MIR" payment cards was due to the population receiving salaries and benefits at the expense of the state.

Cash withdrawals using payment cards are an indicator of user maturity - the fewer such transactions occur, the more mature payment service users are. The number of cash withdrawals increases until 2016 and then decreases. The decline is associated with the onset of stage III - the development of the digital economy and the expansion of alternative payment options [21]. But at the same time, the total volumes of cash withdrawals remain, which is associated, among other things, with the inflationary depreciation of money. On 
the one hand, this indicates the stability of preferences for cash liquidity [30], on the other hand, the underutilization of the potential of non-cash transactions for various reasons [11].

During the COVID-19 pandemic, the Russian population began to abandon the use of cash and use contactless payment methods. We note an acceleration in the decline in cash withdrawals in the first half of 2020 (compared to 2019, the decrease in the first quarter of 2020 was 27.2 million units $(3.84 \%)$ or 569.2 billion rubles $(9.23 \%)$, in the second quarter of 2020 - already 242.1 million units $(30.36 \%)$ or 942.6 billion rubles $(13.24 \%)$ ). Such dynamics is a reflection of the impact of the pandemic and, as a result, a decrease in the income of payment card holders.

The identified trends are a consequence of digitalization. In Russia, the development of the digital economy is one of the main state priorities. For this, the state programs "Digital Economy" have been developed for the main areas of activity. There is no special program for the financial sector, but financial institutions were the first to use digital technologies to serve customers.

The state of the modern payment market in Russia is characterized by the following trends caused by digitalization:

- A symbiosis of financial and non-financial companies is taking place, non-financial companies are expanding their activities and entrenching financial services that were previously provided only by banks.

- Competition between traditional financial intermediaries (banks) and non-banking organizations is increasing on the Russian market.

- The role of fintech companies and large financial platforms is strengthening, the difference between banking products and fintech services is being eliminated, new payment services for retailers are emerging based on local platforms.

- Consumer demand for e-commerce, online transactions and contactless payments is growing.

These phenomena in Russian practice are acquiring stable trends, which are only strengthened under the influence of the pandemic. Progressive changes are taking place due to the fact that Russia has a fairly high level of availability of financial instruments. According to the Bank of Russia, $81.7 \%$ of Russian adults have bank cards, and systems for fast payments between banks within the country have been created. As a result, over the past five years, the share of non-cash payments in retail payment turnover has increased more than 2.5 times and in the first half of 2020 reached $69 \%$. Before the pandemic, many retail consumers (the so-called "underbanked") did not use the available digital services (for example, they received a salary on the card, but withdrew all the money to pay in cash, or opened a deposit in the bank in person, although they could do it in the application, etc.). P.). During the pandemic, the proportion of consumers making extensive use of affordable online services has grown significantly. According to the study of the Russian market of non-cash payments in the second quarter of 2020, conducted by QIWI, the payment turnover on virtual cards increased by $44 \%$ compared to the pre-crisis indicators of the first quarter of 2020, and the average transaction amount on virtual cards - by $12 \%$ (up to 150 US dollars). If in the second quarter of 2019 users made 11 transactions on average using a digital card, then in the second quarter of 2020 there were already 19 transactions.

\section{Conclusion}

As a result of solving the tasks set in the article, the following was established.

1) There are 3 stages in the development of the modern payment market in Russia: Stage I - the introduction of the federal law "On the National Payment System", which became an incentive for the growth of the number of participants in the payment market, the number of transactions (2011-2013); Stage II - the application of external sanctions to the Russian economy, restriction of access to international financing markets (2014-2016); 
Stage III - the development of the digital economy in Russia (2016 -...); Stage IIIA (IV?) the emergence of pandemic shocks and the manifestation of pandemic restrictions (2020 ...). The identification of stages in this time frame is necessary for an adequate assessment of the state of the Russian payment market.

2) To study the state of the payment market in Russia, we analyzed data on the infrastructure for the provision of payment and other financial services, on the number of non-cash payments, and on the use of cash. Since 2010, there has been an annual decrease in the number of banks, caused by various reasons at each stage. The structure of non-cash payments is changing: the number and amount of transactions using payment cards are growing, the number and volume of money transfers are decreasing, and cash is being phased out.

3) The impact of the COVID-19 pandemic and digitalization on the state of the Russian payment market reflects trends that are being strengthened by the pandemic and are shaping a sustainable trend. A symbiosis of financial and non-financial companies is taking place, competition between traditional financial intermediaries (banks) and non-banking organizations is increasing, the role of fintech companies and large financial platforms is strengthening, the difference between banking products and fintech services is being eliminated, new payment services for retailers are emerging based on local platforms, consumer demand for e-commerce, online transactions and contactless payment services is growing.

\section{References}

[1] Akimova OE, Volkov SK, Kabanov VA, Ketko NV, Kuzlaeva I. 2020 WSEAS Transactions on Environment and Development 16 pp 397-412

[2] Averchenko OD 2018 Economics. Business. Banks 5(26) pp 87-96

[3] Babkin AV, Burkaltseva DD, Pshenichnicov VV, Tyulin AC 2017 Journal of Economics $\mathbf{1 0 . 5}$ pp. 9

[4] Baydukova N, Vasilyev S, Chepakov D 2016 Bulletin of Saint-Petersburg state University 1 pp 17-26

[5] Bech ML, Hobijn B 2007 The Case of Real-Time Gross Settlement International Journal of Central Banking 3(3) pp 147-181

[6] Bech M, Preisig C, Soramaki K 2008 Global Trends in Large-Value Payment. FRBNY Economic Policy Peview

[7] Burkaltseva D, Sivash O, Boychenko O, Savchenko L, Bugaeva T, Zotova S 2017 European Research Studies Journal XX 4B pp 366-379

[8] Elmquist M, Gawer A, Le Masson P 2019. European management review 31(3) pp 417-433

[9] Ercevik K, Jackson J 2009 The Quarterly Review of Economics and Finance 49 pp $1-25$

[10] Gawer A, Cusumano M 2014 J. Prod. Innov. Management 31(3) pp. 417-433

[11] Ivanov PI, Burkaltseva DD, Arzumanov RM, Grischenko LL, Zhirnov YuN, Pestov $\mathrm{NN}$, Oleynik AS, Uryadov YuYu 2019 International Journal of Innovative Technology and Exploring Engineering 9(2) pp 4266-4273

[12] Kokhanova VS, Bohon KS 2019 Scientific Bulletin of the Southern Institute of Management 4 pp 84-90

[13] Korobeynikova OM, Korobeynikov DA, Popova LV, Savina OV, Kamilova RS 2017 Espacios 38(62)

[14] Korobov Yu 2015 Science and society 322 pp 39-41

[15] Korobov Yu, Orlova A 2010 Finance, money, investment 3 pp 7-11

[16] Leinonen H, Soramaki K 1999 Bank of Finland Discussion Papers 16 pp 1-55 
[17] Levine R, Loayza N, Beck T 2000 Journal of Monetary Economics 461 pp 31-77

[18] Masiukiewicz Piotr, Dec Paweł 2019 Economics. Law. State 2(4) pp 18-31

[19] Muegge S. 2013 Technology Innovation Management Review 3(2) pp. 5-15

[20] Nelson R, Phelps E 1996 American Economic Review 562 pp 69-75

[21] Pankratova O 2017 Banking 10 pp 38-41

[22] Popova L, Korobeynikov D, Korobeynikova O, Panov A 2016 Journal of Applied Economic Sciences XI 644 pp 1034-1044

[23] Semenyuta O, Panchenko N 2013 Finance and credit 41569 pp 2-7

[24] Skokov RYu 2018 The European Proceedings of Social \& Behavioural Sciences EpSBS L pp 1106-1114

[25] Stepanov DA 2018 Financial life 1 pp 46-50

[26] Stiglitz JE 2020 https://www.project-syndicate.org/commentary/covid-2020recession-how-to-respond-by-joseph-e-stiglitz-2020-06

[27] Stiglitz JE 2020 Finance: Theory and Practice 24(2) pp. 6-21

[28] Stiglitz J, Bhattacharya A 1999 Underpinnings for Stable and Equitable Global Financial System (N.-Y.: World Bank)

[29] Sukhodolov AP, Popkova EG, Kuzlaeva IM 2018 Studies in Computational Intelligence $714 \mathrm{pp} 43-52$

[30] Shvandar KV, Cherkasov VYu 2018 Financial Research Institute. Financial journal 6(46) pp 109-119

[31] Volkov SK, Gushchina EG, Vitaleva EM 2019 Regional and Sectoral Economic Studies 19(2) pp 45-56 